\title{
UNIA POLSKI I LITWY W LATACH 1385-1413 W NAJNOWSZEJ HISTORIOGRAFII POLSKIEJ
}

Połączenie państw polskiego i litewskiego, zapoczątkowane w r. 1385 aktem krewskim i powołaniem Jagiełły, wielkiego księcia litewskiego, na tron polski, w decydujący sposób wpłynęło na bieg ich dziejów. Związek ten otwierał Polsce drogę do nowej strefy interesów na Wschodzie, Litwie zaś, dzięki chrystianizacji, pozwalał na zbliżenie się do kultury Zachodu. Przyszły wielowiekowy związek obu państw zapoczątkowany został przez trzy wydarzenia, mające fundamentalne znaczenie dla jego istnienia. Były to: wydanie przez Jagiełłę aktu krewskiego (14 sierpnia 1385), jego koronacja na króla polskiego (4 marca 1386) i wyjazd na Litwę z początkiem r. 1387 celem uczestniczenia w chrystianizacji Litwinów.

Zestawienie tych dat, w odniesieniu do czasów współczesnych, służy przypomnieniu, że mija właśnie 600 lat od momentu połączenia się dziejów Polski i Litwy. Jest to okazja, by dokonać bilansu osiągnięć i ewentualnych potrzeb naszej historiografii $w$ badaniach nad wydarzeniami początkowego okresu istnienia związku Polski z Litwą. Przedmiotem rozważań będą lata 1385-1413, a więc daty wyznaczone aktami tzw. unii krewskiej i horodelskiej. Przyjęcie takiej cezury czasowej ma swoje uzasadnienie. W latach tych bowiem formowało się dopiero przyszłe oblicze państwa polsko-litewskiego: rozpoczęta w r. 1387 chrystianizacja objęła wówczas tylko Litwę Górną, czyli Auksztotę, natomiast Żmudź pozostała $\mathrm{w}$ pogaństwie jeszcze przez kilkanaście lat. Wprowadzenie chrześcijaństwa na tym terenie było możliwe dopiero po pokoju toruńskim (1411), kiedy Żmudź znalazła się ostatecznie pod panowaniem Jagiełły i Witolda.

Przez wiele lat wypracowywano także prawno-ustrojowy model monarchii polsko-litewskiej. Po wydaniu aktu krewskiego nastąpiły kolejne prawa i przywileje społeczeństwa litewskiego określające położenie Kościoła katolickiego na Litwie oraz stosunek obu państw względem siebie. Ten ostatni aspekt precyzuje unia wileńsko-radomska z r. 1401 i unia horodelska z r. 1413. Oba akty unijne, aczkolwiek nie ustaliły one ostatecznie trwałego modelu monarchii, to jednak zapoczątkowały związek społeczeństwa litewskiego i polskiego, dający podstawę trwałości połą- 
czenia obu krajów. Takie uzasadnienie cezury czasowej, w której zamyka się etap początkowy formowania państwa polsko-litewskiego, nie jest ni-

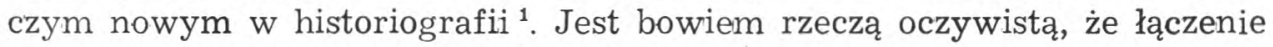
organizmów państwowych dokonuje się powoli, przy współudziale wielu czynników.

Średniowieczne dzieje monarchii polsko-litewskiej były przedmiotem badań wielu wybitnych historyków; zaowocowały one wybitnymi dziełami i pomniejszymi opracowaniami. Historiografia XIX i początku XX wieku zawiera tak wiele syntez dziejów Polski i jej związku z Litwą, że nie sposób byłoby wyliczyć wszystkich autorów. Tuż przed I wojną światową i w r. 1919 powstały dwa wielkie dzieła, traktujące specjalnie o historii polsko-litewskich stosunków państwowych ${ }^{2}$. Owe prace, napisane dla uczczenia okrągłych rocznic unii horodelskiej i lubelskiej, stanowią do dziś podstawę wszelkich badań w tym zakresie. Wówczas także zauważono potrzebę podsumowania dokonań $w$ dziedzinie poznawania Litwy, na tle jej związku z Polską. Bilans taki sporządził w r. 1930 K. Chodynicki ${ }^{3}$. Objął on jednakże tylko niewielki wycinek czasowy, tzn. dziesięciolecie 1920-1930 i to w aspekcie szerszym, czyli badań nad historią Litwy w ogólności. Autor wyróżnił specjalnie okres jagielloński, w nim zaś dziedzinę unii państwowej Polski z Litwą i rozpowszechnienia katolicyzmu na Litwie. $Z$ bilansu Chodynickiego wynika, że pomimo tego, iż $\mathrm{w}$ latach wcześniejszych powstało wiele interesujących prac w tym zakresie, ciągle jednak znajdowali historycy pole do działania.

Spostrzeżenia K. Chodynickiego zdaje się potwierdzać także nowsza historiografia polska okresu powojennego. Właśnie zbilansowaniu dokonań historyków ostatnich dziesięcioleci służyć ma niniejszy artykuł. Przy okazji może uda się także uwidocznić dalsze potrzeby $\mathrm{w}$ badaniach nad początkami unii polsko-litewskiej. Przedmiotem omówienia będą przeważnie prace dotyczące dziejów Litwy w aspekcie jej związku z Polską, wykazjuące ich wzajemne powiązania w różnych dziedzinach życia politycznego, gospodarczego i kulturalnego.

Dokonując przeglądu historiografii dotyczącej zakreślonej wyżej problematyki, należałoby najpierw poświęcić nieco uwagi źródłom. W tej dziedzinie osiągnięcia są niewielkie, jednakże istnieją przyczyny, które uniemożliwiają współczesnym badaczom ich wydawanie. Najważniejszym spośród zbiorów źródeł jest Kodeks dyplomatyczny katedry i diecezji wileńskiej. Jego edycja, przygotowana przez J. Fijałka i W. Semkowicza,

1 J. Dąbrowski, Dzieje Polski średniowiecznej, t. 2, Kraków 1926, s. $274-277$.

${ }^{2}$ Polska $i$ Litwa $w$ dziejowym stosunku, Kraków 1914; O. Ha le cki, Dzieje unii jagiellońskiej, t. 1: W wiekach średnich, Kraków 1919.

${ }^{3} \mathrm{~K}$. Chodynicki, Przeglad badań nad dziejami Litwy $w$ ostatnim dziesięcioleciu (1920-1930). „Kwartalnik Historyczny” 49 (1930) s. 273-300. 
ukazała się w latach $1938-1948^{4}$. Doczekała się także wznowienia część Dziejów Polski Jana Długosza, dotycząca tego okresu ${ }^{5}$. Jest to nowe, krytyczne wydanie w języku łacińskim (ks. 10, 1370-1405) i polskim (ks. 10-11, 1370-1450). Poza tymi wydawnictwami trudno wskazać inne; trzeba by sięgnąć do edycji zagranicznych, to jednak wykracza poza założenia tematyczne niniejszego artykułu ${ }^{6}$.

Omówienie głównych zagadnień związanych z początkami związku polsko-litewskiego wypadałoby rozpocząć od opracowań traktujących o wydarzeniach z lat 1385-1413, a więc o pierwszych aktach unii. Ogólnie omówione zostały przez autorów każdej większej syntezy naszych dziejów. Ze względu na ich dużą ilość wymienić można tylko przykładowo prace Z. Wojciechowskiego, J. Bardacha, K. Tymienieckiego, J. Wyrozumskiego i W. Czaplińskiego ${ }^{7}$. Znalazły się one także na kartach najnowszego opisania dziejów Litwy, pióra J. Ochmańskiego ${ }^{8}$. Specjalne studium, będące nowym spojrzeniem na problem związku polsko-litewskiego, napisał Juliusz Bardach ${ }^{9}$. Przedstawia on w nim swój punkt widzenia na postanowienia zawarte w aktach określających prawno-polityczny stosunek obu państw. Stara się też odpowiedzieć na podstawowe pytanie, stawiane już wielokrotnie przez historyków - czy akt krewski był inkorporacją. Z rozważań autora wynika, że nią nie był, na co przytacza wiele interesujących argumentów. Problemom tym poświęcono także nieco miejsca w bardzo interesującym tomie, dotyczącym polskiego średniowiecza: Polska dzielnicowa $i$ zjednoczona. Państwo, społeczeństwo, kultura, opublikowanym w r. 1972 pod redakcją A. Gieysztora. Zwłaszcza rozdział pt. Polska $w$ dziejach politycznych Europy od połowy XIV do schyłku XV wieku, napisany przez Romana Hecka, zawiera zwięzły opis wydarzeń z lat 1385-

4 Kodeks dyplomatyczny katedry i diecezji wileńskiej, t. 1, wyd. J. Fijałek, W. Semk ow ic z, Kraków 1938-1948 (z. 1-3).

5 Joannis Dlugosii Annales seu Cronicae incliti Regni Poloniae liber X, Varsaviae 1985; Jana Długosza Roczniki czyli Kroniki sławnego Królestwa Polskiego, przekład J. Mrukówna, Warszawa 1982-1985.

${ }^{6}$ Warto jednakże wskazać na niektóre spośród zbiorów obcych źródeł, szczególnie pożytecznych przy opracowywaniu polsko-litewskich zabiegów dyplomatycznych o obronę unili i postępów chrystianizacji wobec pomówień Zakonu Krzyżackiego: Regesta historico-diplomatica Ordinis S. Mariae Theutonicorum, ed. E. J o a chim, W. Hubats ch, t. 1-2, Göttingen 1948; Die Berichte der Generalprokuratoren des Deutschen Ordens an der Kurie, edd. K. Forstreuter, H. K o e p p n, Bd. 1-2, Göttingen 1960-1961; Elementa ad fontium editionis, ed. E. Winkler, t. 2, Roma 1960.

7 Z. Wojciechowski, Państwo polskie w wiekach średnich, Poznań 1945, (wyd. II uzup., Poznań 1948); J. Bardach i in., Historia Polski do r. 1466, Warszawa 1954 (wyd. IV, Warszawa 1960); K. Tymieniecki, Polska $w$ sredniowieczu, Warszawa 1961; J. W y rozumski, Historia Polski do r. 1505, wyd. I, Warszawa 1978; W. Cza pliński, Zarys dziejów Polski do r. 1864, Kraków 1985.

8 J. O chmański, Historia Litwy, Wrocław 1967 (wyd. II popr. i uzup. Wroclaw 1982).

- J. Bardach, Krewo $i$ Lublin. Z problemów unii polsko-litewskiej, „Kwartalnik Historyczny" 76 (1969) $n r 3$ s. $583-619$. 
$1413^{10}$. Ciekawe spojrzenie na tę problematykę zaprezentował także Henryk Samsonowicz w swoim wielce erudycyjnym artykule poświęconym monarchii jagiellońskiej ${ }^{11}$. Autor słusznie zauważa, że unia polsko-litewska nie była aktem jednorazowym, próba wcielenia Litwy do Polski była zamierzeniem nierealnym, jednakże zaistniały okoliczności sprzyjające, które sprawiły, że związek ten mimo wszystko egzystował. Dopiero po Grunwaldzie rozpoczął się proces ujednolicania obu odmiennych społeczeństw. Jego początków, zdaniem autora, można dopatrywać się w unii horodelskiej.

Kwestia stosunku politycznego obu państw nie daje większych możliwości badawczych historykom. Trudno spodziewać się nowych źródeł, które umożliwiłyby zmianę ustalonych już faktów. Pozwala to jednak ciągle na nowo interpretować zagadnienia prawno-ustrojowe, daje możliwość prezentowania nowej wykładni problemu ${ }^{12}$.

Kolejnym ważnym zagadnieniem, składającym się na rozległą problematykę stosunków polsko-litewskich, jest chrystianizacja Litwinów i związane $\mathrm{z}$ nią sprawy tolerancji religijnej. Na uwagę zasługuje artykuł Jerzego Ochmańskiego, w którym przedstawione są przyczyny opóźnienia przyjęcia chrztu przez Litwę ${ }^{18}$. Duży wpływ na to miało pograniczne położenie Księstwa i wynikający stąd alternatywny wybór: czy katolicyzm, czy prawosławie. Decyzję przyspieszyła potrzeba szukania silnego sojusznika pod koniec XIV w. Takim mogło być tylko zjednoczone i umocnione przez Kazimierza Wielkiego państwo polskie. Ciekawe studium Andrzeja Wróblewskiego, będące fragmentem większej pracy, daje ponowny opis chrystianizacji Auksztoty ${ }^{14}$. Oprócz przedstawienia znanych już wydarzeń, autor wyróżnia dwa etapy: pierwszym jest chrzest samego króla i towarzyszących mu bojarów w r. 1386, drugim natomiast działalność Jagiełły i polskich duchownych na Litwie, rozpoczęta w r. 1387. Problem ten przedstawiony został także przez T. Silnickiego w wydanej pod redakcją B. Kumora i Z. Obertyńskiego Historii Kościoła w Polsce ${ }^{15}$

10 Polska dzielnicowa $i$ zjednoczona. Państwo - spoleczeństwo - kultura, pod red. A. Gieysztora, Warszawa 1972; R. He ck, Polska w dziejach politycznych Europy od pot. XIV do schytku XV w., tamże s. 313-368 (zwłaszcza część pt. Unia $z$ Litwa $i$ rozprawa $z$ Zakonem, s. 333-347).

$11 \mathrm{H}$. Sams on ow icz, Polska monarchia Jagiellonów. Kraj, spoleczeństwo, polityka, „Przegląd Humanistyczny” 23 (1979) $\mathrm{nr} 7$ s. $73-88$.

12 Przykładowo można wymienić artykuł H. Łow miańskiego, Wielkie Księstwo Litewskie. Zagadnienia ustrojowe i prawne, „Kwartalnik Historyczny" 79 (1972) $\mathrm{nr} 4$ s. $885-896$.

$18 \mathrm{~J}$. O chmański, Przyczyny opóźnionej chrystianizacji Litwy. Kilka uwag na marginesie referatu Jouzasa Jurginisa: The reasons for the balated dissemination of christianity in the Baltics. Moskwa 1971, XIII Kongres Nauk Historycznych Moskwa 1971 „Kwartalnik Historyczny” 78 (1971) nr 4 s. 870-871.

14 A. Wróblewski, Chrystianizacja Litwy Górnej, „Novum” 1971 nr 7/8 s. $86-99$.

15 Historia Kościoła $w$ Polsce, t. 1: do r. 1764, red. B. Ku mor, Z. O b e rtyński, Poznań 1974. Rozdzial 4 oprac. przez T. Silnickiego (s. 317-319). 
oraz w innym zwięzłym opracowaniu, pióra Marcelego Kosmana ${ }^{\mathbf{1 6}}$. Ten ostatni poświęcił kwestii chrystianizacji Litwy także odrębne studium, gdzie stara się dokonać weryfikacji przyjętych już ustaleń w tej dziedzinie, wydobyć podstawowe momenty w tym zakresie, a także porównać je $\mathrm{z}$ wynikami badań dotyczących tych samych procesów w innych krajach europejskich ${ }^{17}$. Przedstawione najpierw próby chrystianizacji sprzed r. 1386 prowadzą do rozważań nad etapami właściwego chrztu Litwy. Autor wyróżnia trzy takie etapy. Dwa pierwsze zgadzają się z opisanymi wyżej rozważaniami A. Wróblewskiego: etap trzeci to likwidacja pogaństwa na Żmudzi po r. 1411. Szczególnie interesujące są wywody autora na temat synkretyzmu i trudności związanych z likwidacją kultów pogańskich. Wynika $\mathrm{z}$ nich postulat podjęcia badań nad tolerancją religijną. Realizuje go sam autor w kolejnym artykule, poświęconym tej kwestii w ciągu trzech wieków ${ }^{18}$. Odnośnie do interesującego nas okresu ciekawe są spostrzeżenia dotyczące współistnienia katolicyzmu, prawosławia i resztek pogaństwa. Zdaniem autora katolicyzm stał się religią panującą, jednakże dla innych pozostał pewien margines swobód, znacznie szerszy niż w innych krajach Europy Zachodniej. Istniała tolerancja w stosunku do nich, ale nie było równouprawnienia z katolikami. Natomiast nastał kres pogan, chociaż całkowite wykorzenienie pogaństwa było długotrwałym procesem.

Problem ten stał się także przedmiotem rozważań Tadeusza Trajdosa w dwóch jego pracach ${ }^{19}$. Przedstawiając sytuację kościoła prawosławnego, stwierdza, że korzystał on z tolerancji, jednakże pod dwoma warunkami: bezwzględnej lojalności wobec władcy oraz wypełniania jego poleceń. W drugim z wymienionych studiów autora znalazły się interesujące wywody co do prób połączenia, na zasadzie unii, Kościołów katolickiego i prawosławnego, czynionych przez Władysława Jagiełłę. Swiadczą o tym organizowane przez króla dysputy z metropolitą kijowskim Cyprianem, prowadzone dwukrotnie w r. 1404 i 1406. Jest to ciekawy przyczynek do wyświetlenia roli tego władcy w kwestii rozszerzenia nowo przyjętej religii. Idąc dalej w tym kierunku, może udałoby się także pokazać wpływ katolicyzmu na inne religie istniejące na Litwie, albo prześledzić ewen-

16 M. Kosman, Przenikanie katolicyzmu do Europy północno-wschodniej. [w:] Katolicyzm średniowieczny, pod red. J. Kellera. Warszawa 1977, s. 107133.

17 M. Kosman, Pogaństwo, chrześcijaństwo $i$ synkretyzm na Litwie $w$ dobie przedreformacyjnej, „Komunikaty Mazursko-Warmińskie” 16 (1972) $\mathrm{nr} 1 \mathrm{~s}$. $103-137$.

$18 \mathrm{M}$. Kosman, Tolerancja wyznaniowa na Litwie do XVIII $w$. „Odrodzenie i Reformacja w Polsce" 18 (1973) s. 95-123.

${ }_{10} \mathrm{~T}$. Trajdos, Kościół katolicki na ziemiach ruskich Korony i Litwy za panowania króla Wtadysława Jagietły (1386-1434), t. 1, Wrocław 1983. Rozdz. 1: Kościót katolicki na ziemiach pótnocno-wschodnich Rusi litewskiej (s. 27-38); tenże, Metropolici kijowscy Cyprian i Grzegorz Camblak (butgarscy duchowni prawostawni) a problemy cerkwi prawostawnej u schytku XIV $i w$ pierwszej ćwierci XV w., „Balcanica Posnaniensia” 2 (1985) s. 211-234. 
tualne zamiary Jagiełły i Witolda względem szukania nowych obszarów dla religii katolickiej. W pewnym sensie czyni zadość temu postulatowi badawczemu Piotr Borawski, zajmujący się problematyką kolonizacji tatarskiej na Litwie ${ }^{20}$. Witold organizował od r. 1397 liczne wyprawy na tereny tatarskie, w czym Długosz upatruje krucjatę przeciwko niewiernym. Niekiedy uczestniczyło w nich także wojsko polskie. W wyniku tych wypraw zyskiwał książę licznych jeńców, częściowo odsyłanych do Polski, częściowo zaś osadzanych na Litwie. Tatarzy osiadli w Koronie zostali ochrzczeni i ulegli asymilacji, na Litwie jednak prawdopodobnie pozostawali przy swej religii.

Najnowszym studium poświęconym kwestii chrztu Litwy jest artykuł Karola Górskiego, ukazujący ją w szerszym aspekcie, tzn. na tle chrystianizacji innych krajów bałtyckich ${ }^{21}$. Odnośnie do sposobu przeprowadzenia chrystianizacji Litwinów autor słusznie zwraca uwagę na rolę, jaką odegrał w tym sam król. Władysław Jagiełło osobiście uczestniczył w tej akcji, przemawiając do Litwinów w ich języku, a nawet przetłumaczył dla nich na litewski „Ojcze nasz".

Poważne są osiągnięcia naszej powojennej historiografii w badaniach nad przywilejami, ustrojem i uposażeniem biskupstwa wileńskiego, powstałego w r. 1387, a uznanego przez Rzym w r. 1388. Zapoczątkowal je Kazimierz Hartleb artykułem opublikowanym w r. $1946{ }^{22}$. Problematyka ta stała się szerokim polem działania Jerzego Ochmańskiego.

Opublikował on wyniki swoich gruntownych badan w kilku artykułach, uwieńczonych w 1972 r. całościową monografią biskupstwa wileńskiego. Zachowując chronologię wydawnictw, wypada rozpocząc ich omówienie od artykułu poświęconego przywilejom nadanym biskupstwu przez Jagiełłę i Witolda ${ }^{23}$. Oprócz ich przedstawienia, autor zajmuje się także kwestią autentyczności dokumentów donacyjnych z lat: 1387, 1388, 1391, 1395. W kolejnym studium, poświęconym przywilejom na rzecz Kościoła na Litwie, znaleźć można szczegółowe omówienie podstawowych i pomniejszych akt, zapewniających mu szybki rozwój gospodarczy ${ }^{24}$. Biskupstwo

${ }^{20} \mathrm{P}$. Borawski, $\mathrm{Z}$ dziejów kolonizacji tatarskiej $w$ Wielkim Księstwie Litews,kim i w Polsce (XIV-XVII w.), „Przegląd Orientalistyczny” 25 (1977) $\mathrm{nr} 4$ s. 291-304; tenże, Etapy kolonizacji tatarskiej $w$ państwie polsko-litewskim XIVXVI w., „Novum” 20 (1978) s. 123-150.

${ }_{21} \mathrm{~K}$. Górski, Problemy chrystianizacji $w$ Prusach, Inflantach $i$ na Litwie, „Komunikaty Mazursko-Warmińskie” 26 (1983) nr 3 s. 151-168.

${ }_{22} \mathrm{~K}$. Hartle b, „Dla pomnożenia chwaty Bożej”. Jagiełtowe i Jadwigi fundacje i darowizny na rzecz Kościoła $w$ Koronie $i$ Litwie, „Nasza Przeszłość" 1 (1946) s. $5-42$.

28 J. O chmański, Najdawniejsze przywileje Jagiełty $i$ Witolda dla biskupstwa wileńskiego 1387-1395, Poznań 1961, s. 19-36. Zeszyty Naukowe UAM 34: Historia 5.

${ }_{24} \mathrm{~J}$. O chmański, Uprzywilejowanie gospodarcze Kościola katolickiego na Litwie w średniowieczu, „Roczniki Dziejów Spolecznych i Gospodarczych 23 (1961, druk: 1962) s. $89-108$. 
wileńskie szybko stało się dominujące pod względem ekonomicznym posiadaczem na Litwie. Hojne uposażenie, uczynione przez Jagiełłę już w erekcji biskupstwa, spowodowało, że od razu posiadało ono prawdziwe latyfundium. Dzięki uzyskaniu przez Kościół na Litwie szerokich uprawnień $w$ zakresie prawa majątkowego, biskupstwo wileńskie mogło dominować w tym względzie nad feudałami świeckimi. Problematyką dóbr biskupstwa wileńskiego zajął się Jerzy Ochmański w artykule poświęconym gospodarstwu dworskiemu i strukturze społecznej latyfundium ${ }^{25}$, rozszerzonym potem do rozmiarów monografii ${ }^{26}$. Praca ta jest $\mathrm{w}$ pewnym sensie syntezą wcześniejszych badań, opublikowanych we wspomnianych wyżej artykułach. Obejmuje wszystkie elementy składające się na gospodarczy kształt biskupstwa w latach 1397-1550. W interesującym nas okresie na uwagę zasługują ustalenia odnośnie do jego pierwotnego uposażenia oraz uformowania się podstaw latyfundium, jak również przekrojowy obraz stosunków społeczno-gospodarczych. Kompleksowe opracowanie średniowiecznych dziejów biskupstwa wileńskiego zawiera monografia opublikowana przez Jerzego Ochmańskiego w r. $19722^{27}$. Tematyka społeczno-ekonomiczna, znana już z poprzednich prac tegoż autora, uzupełniona została nowymi kwestiami. Sporo miejsca poświęcił on biskupom, kapitule wileńskiej i parafiom. Stroną gospodarczą funkcjonowania biskupstwa wileńskiego zajął się także Stanisław Kasperczak przy okazji omawiania gospodarki folwarcznej na Litwie i Białorusi ${ }^{28}$. Studium to, w interesującej nas kwestii, nie wnosi nic ponad to, co zawarte zostało w pracach Jerzego Ochmańskiego. Wobec dość sporej literatury poświęconej biskupstwu wileńskiemu, trudno wskazać na potrzeby badawcze w tym zakresie. Ukierunkowanie badań raczej ku problematyce społeczno-gospodarczej sugeruje zapotrzebowanie na badania w dziedzinie ogólnie pojętej kościelnej sfery działalności biskupstwa.

Wśród zagadnień dotyczących stosunków polsko-litewskich w ich początkowym okresie na czoło wysuwa się problem wpływu unii i nowych form ustrojowych na kształtowanie się oblicza społeczeństwa litewskiego. Litwa posiadała w chwili łączenia się z Polską swoją odrębną strukturę społeczną i właściwe jej stosunki, oparte przeważnie na prawie zwyczajowym. W nowej sytuacji pozostała otwarta na wszelkie nowości, jakie

$25 \mathrm{~J} . \quad$ Ochmański, Renta feudalna $i$ gospodarstwo dworskie $w$ dobrach biskupstwa wileńskiego od końca XIV do połowy XV w. Poznań 1961, s. 37-94. Zeszyty Naukowe UAM 34: Historia 5.

${ }_{26} \mathrm{~J}$. O chmański, Powstanie $i$ rozwój latyfundium biskupstwa wileńskiego 1387-1550. Ze studium nad rozwojem wielkiej wtasności na Litwie i Biatorusi, Poznań 1963. Prace Wydz. Fil.-Hist. UAM, seria Historia 13.

$27 \mathrm{~J} . \mathrm{O} \mathrm{chmański}$, Biskupstwo wileńskie $w$ średniowieczu. Rozwój $i$ uposażenie, Poznań 1972. Prace Wydz. Fil.-Hist. UAM, seria Historia 55.

${ }_{28} \mathrm{~S}$. Kasperczak, Rozwój gospodarki folwarcznej na Litwie $i$ Białorusi do polowy XV w., Poznań 1965. 
dawał jej związek z Polską. Jej struktura społeczna w zasadzie nie uległa zburzeniu, chociaż pewne zmiany przyniosły ze sobą przywileje Jagiełły i Witolda. Znakomity przegląd społeczeństwa litewskiego w interesującym nas przedziale czasowym, a także w przeciągu całego XV wieku, prezentuje studium Witolda Kamienieckiego, opublikowane w r. $1947^{29}$. Dokonana przez niego analiza władzy książęcej, przywilejów ziemskich i wynikających stąd stosunków społecznych dała w pewnym sensie asumpt Henrykowi Łowmiańskiemu do ponownego zajęcia się tą problematyką ${ }^{30}$. Autor znanych, drukowanych jeszcze przed wojną prac poświęconych społeczeństwu litewskiemu ${ }^{\mathbf{8 1}}$, w swoim artykule zastanawia się, czy przemiany społeczne, jakie zaszły na Litwie w czasach Jagiełły, należy określić mianem rewolucji, czy też ewolucji. Swoje rozważania snuje także wokół problemu poruszonego przez W. Kamienieckiego, czy przywileje Jagiełły z r. 1401 i 1413 stworzyły ustrój rodowy na Litwie. Jednakże problematyka struktury społeczeństwa litewskiego, będąca przedmiotem rozważań obu autorów, nie wyczerpuje w sposób ostateczny wszystkich kwestii i jak najbardziej daje pole do badań następnym historykom.

Zagadnieniom struktury narodowościowej społeczeństwa litewskiego oraz stosunków językowych i etnicznych poświęcił swe studium, wydane na emigracji, Władysław Wielhorski ${ }^{32}$. Doszedł on do wniosku, że Jagiełło i Witold, chcąc ratować swój kraj, dokonali jakby ,rewolucji z góry", narzucili Litwie wraz z unią nową rzeczywistość. Początkowo posługiwali się Polakami, zwłaszcza przy chrystianizacji, potem jednakże działali poprzez samych Litwinów. Wśród licznych narodowości zamieszkujących Litwę znajdowali się także Polacy. W latach $1385-1413$ byli to głównie duchowni oraz nieliczni kupcy i rzemieślnicy, którzy mimo obdarzania ich przez książąt przywilejami, nigdy nie stanowili większej grupy społecznej.

Połączenie się państw polskiego i litewskiego miało także wpływ na rozwój zainteresowań osadnictwem na pogranicznych obszarach Polski. Kwestii tej poświęcił bardzo interesujący artykuł Jerzy Wiśniewski ${ }^{33}$. Zdaniem autora pod koniec XIV w. rozpoczął się długotrwały proces zasiedlania północno-wschodnich obszarów Korony. Pierwszy etap tej kolo-

${ }^{29} \mathrm{~W}$. Kamieniecki, Społeczeństwo litewskie $w$ XV $w$., Warszawa 1947.

${ }^{80} \mathrm{H}$. Ło w miańs $\mathrm{ki}, \boldsymbol{Z}$ zagadnieñ spornych spoleczeństwa litewskiego $w$ wiekach średnich, „Przegląd Historyczny” 40 (1949) s. 96-127.

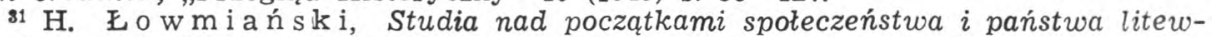
skiego, t. 1-2, Wilno 1931-1932; tenże, Uwagi $w$ sprawie podłó̇̇ społecznego $i$ gospodarczego unii jagiellońskiej, Wilno 1934.

$32 \mathrm{~W}$. Wielhorski, Stosunki językowe, wyznaniowe $i$ etniczne $w$ Wielkim Księstwie Litewskim pomiędzy XIII a XVIII w., „Teki Historyczne” 13 (1964/5, druk: 1966) s. $17-40,225-226$.

${ }_{33} \mathrm{~J}$. Wiśniewski, Rozwój osadnictwa na pograniczu polsko-prusko-litewskim od końca XIV do połowy XVII w., ,Acta Baltico-Slavica” 1 (1964) s. 115135 . 
nizacji objął Wschodnie Mazowsze, część właściwego Podlasia, skrawki ziem nad Narwią i Bugiem i południową część Jaćwieży. Osiedlali się tam głównie Polacy, pochodzący z Mazowsza, poza tym ludność ruska, litewska i resztki osadników jaćwięskich. Przyciągała ich na te tereny bezpieczna granica, możliwe że i przechodzący tędy szlak handlowy z Litwy w kierunku zachodnim.

$\mathrm{W}$ ten sposób pojawia się $\mathrm{w}$ rozważaniach nad osiągnięciami nowszej historiografii polskiej kolejny aspekt związku Polski i Litwy mianowicie kwestia wzajemnych korzyści stąd wynikających. Chodzi tu o korzyści gospodarcze. Litwa wprawdzie od dawna prowadziła wymianę handlową z Polską, lecz w nowej sytuacji możliwa była szersza penetracja, którą zainteresowane były obie strony. Kwestii polsko-litewskich stosunków gospodarczych poświęcił swe studium Adam Kersten ${ }^{34}$. Ujął on tę problematykę w szerszym aspekcie, tzn. stosunków także z miastami niemieckimi i Nowogrodem Wielkim. Do najwcześniejszych autor zalicza kontakty litewsko-lubelskie (już od r. 1383) oraz litewsko-mazowieckie, a także z Krakowem poprzez Lublin. W pierwszych dziesiątkach lat XV w. nawiązały się także silniejsze nici wymiany między Brześciem Litewskim a Warszawą. W rozważaniach nad polsko-litewskimi kontaktami handlowymi dalej idzie Hanna Zaremska ${ }^{35}$. Wprawdzie jako cel swej pracy wytyczyła sobie szukanie związków między rozwojem małych miast a przebiegiem dróg handlowych, daje jednak także ciekawe spostrzeżenia na temat szlaków handlowych polsko-litewskich. Towary wędrowały z Litwy dwoma szlakami: przez Mazowsze i przez Lublin, i dwoma szlakami opuszczały Polskę: przez Gdańsk i przez Wrocław. Miasta mazowieckie i Lublin były punktami docelowymi dla towarów litewskich, przez nie także przebiegały szlaki tranzytowe. Najważniejszy jest końcowy wniosek autorki: w połączeniu $\mathrm{z}$ Wilnem widzi ona wzrastającą prosperity obszarów Lubelszczyzny i Mazowsza.

Ścisły związek z unią polsko-litewską ma także pojawienie się prawa niemieckiego na Litwie. Chrzest Jagiełły rozszerzył obszar lokacji miast w oparciu o wzory polskie. Problematyka ta znalazła wyraz w artykule Józefa Matuszewskiego, który prześledziwszy lokacje na Litwie stwierdził, że prawo niemieckie nie zostało rozciągnięte na wsie, tak jak w Polsce, lecz jedynie na miasta, przez co odegrało na Litwie mniejszą rolę ${ }^{36}$. Nie przekroczyło ono także granic Wielkiego Księstwa. Recepcji prawa

${ }^{34}$ A. Kersten, Kontakty gospodarcze Wielkiego Nowogrodu $z$ Litwq, Polskq i miastami potudniowoniemieckimi $w \times V$ w. "Slavia Orientalis" 7 (1958) s. 130166.

${ }^{35} \mathrm{H}$. Z Z a remska, $\mathrm{Z}$ dziejów handlu polsko-litewskiego. Lokacje $w$ Koronie i na Mazowszu 1386-1501, "Przegląd Historyczny” 64 (1973) z. 4 s. 717-728.

${ }^{36} \mathrm{~J}$. Matuszewski, Recepcja prawa niemieckiego $w$ Polsce $i$ na Litwie, [w:] Sprawozdania z Czynności i Posiedzeń É́dzkiego Towarzystwa Naukowego, t. 20, Łódź 1966, nr 9. 
magdeburskiego na Litwie poświęcił interesujące studium Juliusz Bardach ${ }^{87}$. Rozważania wokól tej kwestii prowadzą autora do wniosku, że prawo niemieckie pojawiło się na Litwie nie dzięki dążeniom mieszczaństwa, lecz było rezultatem odgórnej działalności władcy. Nadawanie tego prawa było wyłącznie uprawnieniem panującego. W dziejach Wielkiego Księstwa autor wyróżnia trzy etapy natężenia nadań prawa magdeburskiego, z których pierwszy, szczególnie w nie obfitujący, przypadł na schyłek XIV w. i początek w. XV. Kwestii tej dotyka także praca Andrzeja Janeczka ${ }^{38}$, w której autor zastanawia się nad przyczynami niedostępności osadnictwa na prawie niemieckim dla ludności ruskiej. Praktyka ta występowała na zachodnim pograniczu Księstwa Litewskiego, a także na innych obszarach wschodnich, zamieszkiwanych przez Rusinów. Klauzule „exceptis scismaticis” znalazły się w wielu przywilejach lokacyjnych Jagiełly i Witolda (np. Kowno). Zdaniem autora, nie wynikały one z segregacji etnicznej czy wyznaniowej, lecz raczej z obawy, by atrakcyjność nowego prawa nie spowodowała porzucania praw własnych. Problem wprowadzenia prawa magdeburskiego na Litwie daje jeszcze historykom duże możliwości badawcze.

Jedną z przyczyn połączenia się Litwy z Polską była potrzeba zyskania silnego sojusznika w celu przeciwstawienia się Zakonowi Krzyżackiemu. W pierwszych latach unii wysunęly się na czoło dwie ważne kwestie z tym związane. Pierwszą była konieczność obrony terytorium Litwy przed krzyżackimi planami zajęcia Żmudzi, drugą zapobieganie zamiarom rozbicia unii i wystąpieniom przeciwko Jagielle na forum europejskim. Sprawa pierwsza znalazła swe rozwiązanie w wojnie 1409-1411 r., której punktem szczytowym była bitwa pod Grunwaldem. Była ona już wielkrotnie przedmiotem badań historyków. W nowszej historiografii stała się szczególnym polem działania Stefana Kuczyńskiego. Autor poświęcił tej kwestii wiele artykułów i pomniejszych prac; ukoronowaniem ich było całościowe opracowanie, opublikowane po raz pierwszy $\mathrm{w}$ r. $1955^{80}$. Z punktu widzenia udziału Litwinów w tej wojnie wyróżnić należałoby dwie spośród szczegółowych prac S. Kuczyńskiego. Pierwsza dotyczy zadań powierzonych skrzydłu litewsko-ruskiemu w samej bitwie ${ }^{40}$, druga omawia warunki pokoju kończącego wojnę, zawartego w Toruniu 1 lutego

37 J. B a rdach, Miasta na prawie magdeburskim $w$ Wielkim Księstwie Litewskim od schytku XIV do połowy XVI stulecia, „Kwartalnik Historyczny” 87 (1980) $\mathrm{nr} 1$ s. $21-51$.

${ }_{38}$ A. Janeczek, Exceptis scismaticis. Upośledzenie Rusinów $w$ przywilejach prawa niemieckiego Wtadystawa Jagielty, „Przegląd Historyczny” 75 (1984) z. 3 s. $527-542$.

so S. M. Ku czyński, Wielka wojna z Zakonem Krzyżackim w latach 14091411, Warszawa 1955 (wyd. IV popr. Warszawa 1980).

${ }^{40} \mathrm{~S}$. M. K u c z y ński, Taktyka walki skrzydła litewsko-ruskiego $w$ bitwie pod Grunwaldem, „Studia i Materiały do Historii Wojskowości” 10 (1964) cz. 2 s. $35-46$. 
1411 r. ${ }^{41}$ Postanowienia pokojowe były przede wszystkim korzystne dla Litwy, zyskiwała ona, wprawdzie nie na zawsze, Żmudź.

Sprawy obrony Litwy przed Krzyżakami znalazły wyraz także w pracach innych autorów. Służy temu wyczerpujące studium Henryka Łowmiańskiego, traktujące o tej kwestii od XII do XV wieku ${ }^{42}$. Z problematyką tą związane jest wielce pożyteczne i solidne studium poświęcone kartografii Wielkiego Księstwa Litewskiego, opublikowane przez Stanisława Alexandrowicza ${ }^{43}$. Szczególnie istotny dla naszego okresu jest rozdział poświęcony mapom wojskowym, w nim natomiast uwagi dotyczące map, relacji zwiadowców lub ewentualnych planów strategicznych, które ułatwiały Jagielle opracowywanie strategii wojskowej.

Drugi problem, postawiony w związku z unią polsko-litewską, a dotyczący zapobiegania krzyżackim planom rozbicia unii, nie stał się jeszcze przedmiotem pełnej eksploracji historyków. Sprawie tej poświęcił swój szkic Leszek Winowski ${ }^{44}$. Znalazła ona także odzwierciedlenie $\mathrm{w}$ bardzo interesującej pracy Andrzeja Feliksa Grabskiego ${ }^{45}$. W rozdziale: Geneza unii Polski $z$ Litwa, autor ten przedstawił nie tylko zabiegi krzyżackie, zmierzające do nastawienia czołowych dworów europejskich przeciwko Jagielle, lecz także podważenia jego pozycji w Kurii. W części pracy dotyczącej oceny Grunwaldu opisuje potyczki dyplomatyczne Polski i Litwy z Zakonem co do właściwego przedstawienia europejskiej opinii publicznej przyczyn i przebiegu konfliktu 1409-1411 r.

Rozważania na temat stosunków Polski i Litwy z Krzyżakami prowadzą do omówienia prac dotyczących działalności dyplomatycznej obu państw. W tej dziedzinie dysponujemy już całościowym opracowaniem: Historia dyplomacji polskiej, wydawana pod redakcją Gerarda Labudy. W tomie pierwszym, poświęconym średniowieczu, odnośne rozdziały napisał Zenon Hubert Nowak ${ }^{46}$.

Z połączenia Polski i Litwy, dwóch państw zróżnicowanych pod względem poziomu cywilizacyjnego, wynikała konieczność przejęcia przez Wielkie Księstwo pewnych instytucji czy urzędów funkcjonujących już w Koronie. Prowadzenie działalności dyplomatycznej, a także potrzeba

41 S. M. K u czyński, Pierwszy pokój toruński, 1 II 1411 r., „Zapiski Towarzystwa Naukowego w Toruniu" 20 (1954) z. 1/4 s. 139-165.

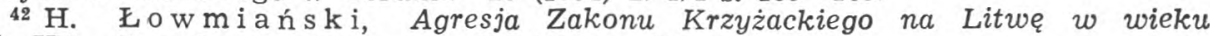
$X I I-X V$, „Przegląd Historyczny” 45 (1954) s. 338- 371.

43 S. Alexandrowic z, Rozwój ,kartografii Wielkiego Księstwa Litewskiego od XV do połowy XVI w., Poznań 1971 (druk: 1972).

${ }_{44} \mathrm{~L}$. Win ow ski, Sprawa stosunku do pogan $w$ polsko-krzyżackim procesie $z$ lat 1412-1414, Wrocław 1956. Zeszyty Naukowe Uniwersytetu Wrocławskiego. S. A, nr 6 (Prawo) z. 2 s. 99-117.

45 A. F. Grabski, Polska w opiniach Europy Zachodniej XIV-XV w. Warszawa 1968 , s. $179-292$.

${ }^{46}$ Historia dyplomacji polskiej, pod red. G. L a bu dy, T. 1: Połowa X w.-1572 , pod red. M. B i s k u a, Warszawa 1982, s. 318-332. 
wystawiania wielu dokumentów, wymagały sprawnej kancelarii. Przed r. 1385 kancelaria funkcjonowała na Litwie w ograniczonym zakresie. Jej rozwój po zawarciu unii był możliwy dzięki przejęciu wzorów polskich w zakresie dyktatu dokumentów oraz dzięki posłużeniu się wręcz polskim personelem kancelaryjnym. Gruntowne badania dotyczące tej kwestii przeprowadził Marceli Kosman. Zaowocowały one trzema pracami poświęconymi dokumentom Jagiełły dla Wielkiego Księstwa i dyplomom Witolda oraz całościowym studium o kancelarii wielkoksiążęcej ${ }^{47}$. Ciekawe są ustalenia autora odnośnie do kolejnych etapów kształtowania się kancelarii Witolda oraz rodzajów wystawianych przez niego dokumentów. $\mathrm{Z}$ pewnością pożyteczne byłyby dalsze badania, zmierzające do całościowego opracowania wpływu Polaków na rozwój ustrojowy i kulturalny Litwy.

Problematyką recepcji innego urzędu polskiego na Litwie, a mianowicie chorążego, zajął się Witold Kamieniecki. Jego badania dotyczące pojawienia się na początku XV w. chorążych w Wielkim Księstwie, niewątpliwie wskazują na polską ich proweniencję. Geneza chorąstwa wynikała z potrzeb wojskowości litewskiej ${ }^{48}$.

Interesującą kwestią w dziedzinie stosunków polsko-litewskich są także wzajemne kontakty obu społeczeństw. Potrzeby w tej dziedzinie częściowo zaspokajają prace Władysława Wielhorskiego i Ireneusza Janika. Studium pierwszego autora, opublikowane na emigracji, przynosi ciekawe ustalenia na temat okazji do wzajemnych kontaktów ${ }^{40}$. Dawały je niewątpliwie wojny oraz wymiana handlowa. I. Janik stara się zasygnalizować pewne cechy charakteryzujące stosunek Polaków do Litwinów i Litwy, a także do samego Jagiełły, w pewnym sensie władcy obcego. Szkic ten jest skrótem większej pracy ${ }^{\text {s0 }}$.

Okazję do ściślejszego zbratania obu narodów dała unia horodelska. 48 rodów szlacheckich przyjęło wówczas do swoich herbów 48 przedstawicieli rodów książęcych i bojarskich z Litwy. Wśród Litwinów, którzy zostali wybrani, wielu już wcześniej pojawiło się na arenie politycznej. Niewątpliwie ważną potrzebą jest przebadanie dziejów niektórych przynajmniej przedstawicieli rodów, przyjętych wówczas do polskich herbów.

47 M. Kosman, Dyplomy Władysława Jagietty dla Wielkiego Księstwa Litewskiego, „Archeion" 48 (1968) S. 45-59; tenże, Dokumenty tacińskie wielkiego "księcia Witolda, "Archeion" 51 (1969) s. 73-89; tenże, Dokumenty wielkiego księcia Witolda, "Studia Źródłoznawcze" 16 (1971) s. 139-169; tenże, Kancelaria wielkiego księcia "Witolda, „Studia Źródłoznawcze” 14 (1969) s. 91-119.

${ }_{48} \mathrm{~W}$. Kamienie cki, Chorqżowie $w$ parlamentaryzmie litewskim przed uniq lubelskq, „Antemurale” 9 (1965) s. 165-203.

$40 \mathrm{~W}$. Wielhorski, Polska i Litwa. Stosunki wzajemne $w$ biegu dziejów, Londyn 1947.

so I. J a nik, Litwa $i$ Litwini $w$ świadomości spoleczeństwa polskiego $w$ wiekach średnich (fragment większego opracowania), Łódź 1983, s. 33-53. Acta Universitatis Lodzensis. Folia Historica 14. Wspomniane opracowanie nie ukazało się dotąd w całości. 
W pewnym sensie postulatowi temu czynią zadość Wojciech Peltz i Krzysztof Pietkiewicz. Pierwszy z autorów zajął się rodem Giedygołda, którego przedstawiciel - Jerzy Giedygołd — był jednym ze świadków podpisania pokoju toruńskiego 1 lutego 1411 r. ${ }^{51}$ Drugi poświęcił swe bardzo ciekawe studium Kieżgajłom ${ }^{52}$. Dwaj członkowie tego rodu, Rumbold i Kieżgajło Wolimuntowice, wielce zasłużyli się w akcji misyjnej prowadzonej na Żmudzi.

Osiągnięcia polskiej historiografii powojennej na polu badań nad stosunkami polsko-litewskimi w początkowym okresie unii przedstawione zostały powyżej w pewien uporządkowany sposób. Ukazano tu rezultaty badań obejmujących różne dziedziny, ale ograniczono się tylko do prac specjalnie im poświęconych, pomijając przeważnie te, w których problematyka litewska jest siłą rzeczy obecna jako składnik dziejów Polski. Gdyby uwzględnić wszystkie prace dotykające problematyki Litwy, lista ich byłaby o wiele większa. Pominięto je, o ile nie wnoszą do zakreślonej tu problematyki nic nowego. Warto jednakże zwrócić uwagę na pewne prace biograficzne, by przy tej okazji wskazać na konieczność podjęcia nowych studiów w tej dziedzinie. Na pierwszy plan wysuwają się główne postaci w państwie polsko-litewskim: Władysław Jagiełło i wielki książę Witold. Oprócz powstałych przed wojną monografii obu władców ${ }^{\mathbf{5 3}}$, znane są w nowszej historiografii tylko popularno-naukowe opracowania Marcelego Kosmana i Stefana Kuczyńskiego ${ }^{54}$. Warto byłoby jednakże opracować obszerniejsze, naukowe studia poświęcone obu postaciom. Stosunkowo liczne są publikacje traktujące o życiu królowej Jadwigi Andegawenki ${ }^{55}$, której rola w chrystianizacji Litwy została już dobrze wyświetlona.

Miarą zainteresowań Litwą i stosunkami polsko-litewskimi w historiografii powojennej są publikacje studiów specjalnie poświęconych tej problematyce. Sa to zbiory artykułów wydane pod redakcją jednego historyka, albo zbiory studiów napisanych przez jednego autora. Do grupy pierwszej zaliczyć należy tom powstały pod redakcją znanego badacza dziejów Litwy Jerzego Ochmańskiego ${ }^{58}$. Zawiera on osiem studiów o róż-

$51 \mathrm{~W}$. Peltz, Ród Giedygołda $i$ jego majętności. Z dziejów tworzenia się wielkiej własności ziemskiej $w$ Wielkim Księstwie Litewskim $w$ XV w., Poznań 1971, s. 23-44. Zeszyty Naukowe UAM 74. Historia 11.

${ }_{52} \mathrm{~K}$. P i etkiewicz, Kieżgajłowie $i$ ich latyfundium do potowy XVI $w$. Ze studiów nad rozwojem własności ziemskiej $w$ Wielkim Księstwie Litewskim w średniowieczu, Poznań 1982.

${ }_{58}$ A. P r ochaska, Król Władysław Jagielło, t. 1-2, Kralków 1908; tenże, Dzieje Witolda, wielkiego księcia Litwy, Wilno 1914.

54 M. Kosman, Wielki ksiqżę Witold, Warszawa 1967; tenże, Wtadystaw Jagiełlo, Warszawa 1968 (obie w serii: Swiatowid); S. M. Kuczyński, Władystaw Jagietto 1350-1434, Warszawa 1971 (w serii BKD).

55 Np. J. R a dli ca, Królowa Jadwiga, [w:] Sacrum Poloniae Millenium, t. 4, Rzym 1957, s. 69-116. Także inme wydawnictwa popularme.

${ }_{58}$ Studia $z$ dziejów Wielkiego Księstwa Litewskiego XIV-XVIII wieku, pod 16 - Analecta Cracoviensia 
norodnej tematyce. Do drugiej natomiast należą zebrane szkice, publikowane także oddzielnie, Juliusza Bardacha ${ }^{57}$ oraz fragmenty większych prac i artykuły Henryka Łowmiańskiego ${ }^{58}$. Obydwa zbiory są wielce pożytecznymi publikacjami, odznaczającymi się bogactwem i różnorodnością treści.

W podsumowaniu należałoby stwierdzić, że tematyka litewska jest chętnie podejmowana przez polskich historyków. Wciąż jednak widać, że możliwości badawcze $\mathrm{w}$ tej dziedzinie są duże. Badanie przeszłości Litwy jest bardzo ważne także z punktu widzenia dziejów Polski. Bez bliższej znajomości wzajemnych więzów obu krajów wszelkie syntezy historii Polski będą niepełne. Trzeba wszakże przyznać, że przemiany, jakie nastapiły po ostatniej wojnie, nie pozostały bez wpływu na stanowisko polskiej historiografii w sprawie stosunków polsko-litewskich. Wizja Polski jagiellońskiej jak gdyby się oddaliła, w badaniach historycznych musi jednak wciąż powracać ku pożytkowi zarówno Polaków, jak i Litwinów.

\author{
DIE POLNISCH-LITAUISCHE UNION IN DEN JAHREN 1385-1413 \\ IN DER POLNISCHEN HISTORIOGRAPHIE DER GEGENWART
}

\title{
Z u s a m m e f a s s u n
}

Die Vereinigung Polens und Litauens wurde durch drei Ereignisse initiiert: das Bündnis zu Krewo bei Wilna (14. August 1385), die Krönung Jagellos zum König Polens (4. März 1386) und die zu Anfang des Jahres 1387 begonneme Christianisierung der Litauer. Der sechshundertste Jahrestag dieser für die künftige Union dieser beiden Länder so bedeutenden Geschehnisse gibt Anlaß zu einer Bilanz der Errungenschaften der polnischen Historiographie auf dem Gebiet der polnisch-litauischen Beziehungen.

Gegenstand der vorliegenden Besprechung sind die Leistungen der polnischen Historiker der Nachkriegszeit auf dem Gebiet der Gestaltung der polnisch-litauischen Beziehungen i. d. J. 1385-1413. Aus diesem Gebiet lassen sich zahlreiche einzelne Probleme erwähnen. Diese betreffen das Entstehen eines Modells des künftigen Staates hinsichtlich seiner Politik und Gesellschaftsordnung (vgl. Anm. 4-12), die Verbreitung des Christentums und die damit verbundene Toleranz der Religion gegenüber sowie verschiedene Ebenen polnisch-litauischer Kontakte (vgl. Anm. 13-

red. J. Ochmańskiego, Poznań 1971. Zeszyty Naukowe UAM 74. Historia 11.

57 J. Bardach, Studia $z$ ustroju $i$ prawa Wielkiego Księstwa Litewskiego $X I V-X V I I w$. Warszawa 1970. Prace Białostockiego Tow. Naukowego 13.

58 H. Łowmiański, Studia nad dziejami Wielkiego Księstwa Litewskiego, Poznań 1983. 
21). Ein gesondertes Problem stellen die Forschungsergebnisse aus dem Bereich der Privilegien, der Gesellschaftsordnung und der Bezüge des Bischofstums Wilnas (vgl. Anm. 22-28). Ein für die Historiker interessantes Problem sind auch die Wandlungen innerhalb des litauischen Volkes sowie die Rezeption der verschiedenen polnischen Institutionen und Ämter in Litauen (z. B. der Diplomatik und des Kanzleiwesens, vgl. Anm. 29-33, 47-50).

Das nächste von den Forschern der Problematik der polnisch-litauischen Beziehungen berührte Problem sind die aus diesem Bündnis hervorgehenden gegenseitigen Vorteile, besonders auf dem Gebiet des Handelsaustauschs, der das Entstehen neuer Handelswege und die Entwicklung der Städte förderte (vgl. Anm. 34-38). Gegenstand des Interesses der Forscher sind ebenfalls die polnisch-litauischen sowohl diplomatischen als auch bewaffneten Kämpfe mit dem Deutschen Orden (vgl. Anm. 39-46) sowie die Bemühungen um die Erhaltung und die Fortentwicklung der Union zwischen den beiden Ländern. Diese Problematik fand besondere Anerkennung bei solchen Forschern wie H. Eowmiański, J. Bardach, J. Ochmański, S. M. Kuczyński sowie zahlreichen anderen, die ihr eine große Anzahl von Arbeiten und kürzerer Bearbeitungen widmeten (vgl. Anm. 51-58). Die Vielfalt der von ihnen berührten Probleme zeugt von den bedeutenden Forschungsmöglichkeiten auf diesen Gebiet. Die vorstehende Analyse weist auf weitere Forschungsbedürfnisse auf diesem Gebiet hin, das noch immer ein Tätigkeitsfeld für die Historiker der Gegenwart darstellt. Dieses ist nämlich unentbehrlich für die weitere Ergründung und die Erkenntnis der gemeinsamen Geschichte des polnischen und des litauischen Volkes. 